\title{
A diachronic analysis of the language of AIDS in Armistead Maupin's Tales of the City
}

Analyse diachronique du vocabulaire du SIDA dans les Chroniques de San

Francisco d'Armistead Maupin

\section{Christelle Klein-Scholz}

\section{OpenEdition}

Electronic version

URL: http://journals.openedition.org/asp/4997

DOI: $10.4000 /$ asp.4997

ISSN: 2108-6354

\section{Publisher}

Groupe d'étude et de recherche en anglais de spécialité

Printed version

Date of publication: 1 March 2017

Number of pages: 179-171

ISSN: 1246-8185

\section{Electronic reference}

Christelle Klein-Scholz, «A diachronic analysis of the language of AIDS in Armistead Maupin's Tales of the City", ASp [Online], 71 | 2017, Online since 01 March 2018, connection on 01 November 2020. URL :

http://journals.openedition.org/asp/4997 ; DOI : https://doi.org/10.4000/asp.4997

This text was automatically generated on 1 November 2020.

Tous droits réservés 


\title{
A diachronic analysis of the language of AIDS in Armistead Maupin's Tales of the City
}

\author{
Analyse diachronique du vocabulaire du SIDA dans les Chroniques de San \\ Francisco d'Armistead Maupin
}

Christelle Klein-Scholz

1 The paper focuses on Armistead Maupin's Tales of the City series, an American body of literature that was considered as "the first fiction [...] to acknowledge AIDS." ${ }^{1}$ This body of literature goes against Oscar Wilde's statement that "all art is quite useless" (1890: 4); it can be termed "art" without the shadow of a doubt, and yet also has a specific purpose. This literature, which is often referred to as "AIDS literature," ${ }^{2}$ consists of a number of novels that were written and published in the early years of the HIV/AIDS epidemic, i.e., the 1980s and early 1990s, and that are still being written and published, though the pace of publication has significantly declined. Those novels, of which Armistead Maupin's Tales of the City series is one example among many, are mostly authored by gay men, ${ }^{3}$ and they stand at a crossroads between art and activism: they can be thought of as works of art and they also feature elements whose goal in the early years of the HIV/AIDS epidemic was to circulate knowledge about this new epidemic that was spreading among "disenfranchised" communities ${ }^{4}$ without the rest of the population taking full measure of the catastrophe. It is worth looking into the way the language of AIDS has evolved in those novels, because time is of the essence when it comes to HIV/AIDS in the 1980s and early 1990s: it took many years and many deaths for public authorities, mainstream media and the rest of the population to grasp what was at stake. It also took activism-several forms of activism, one of which was the publication of the novels in question. Another one was the creation of strong-willed activist associations, the best example being ACT UP, the "AIDS Coalition to Unleash Power whose motto is "SILENCE = DEATH" and one of whose goals was to empower people with AIDS, notably through language, as its motto indicates. This paper first gives some insights into the language of AIDS, then takes a closer look at the "before" 
picture and at the "after" picture, 1996 being the great divide, i.e., the year when antiretroviral therapies were developed, changing the very nature of HIV/AIDS.

\section{Do you speak AIDS? Terminological clarifications}

2 Although most people know that "AIDS" stands for "Acquired Immune Deficiency Syndrome," and therefore that AIDS is a "syndrome," not a "disease," the use of the word "disease" is, strikingly, almost systematic, whether it be in literature or in mainstream media. Several scholars have reflected upon this inaccuracy, and it seems that the explanation lies in what people expect from a diagnosis: in our postmodern times, ${ }^{5}$ a diagnosis is meant to unite a set of symptoms under a readable banner, a label that can be understood. A "disease" is something everyone understands; a "syndrome," however, is precisely a set of clinical signs and symptoms. As a result, the word "syndrome" is exactly what people do not want from a diagnosis: the medical establishment is expected to come up with words that simplify and unite symptoms. This is why the word "disease" is still used: inaccuracy is chosen over unreadability.

Most people know what "AIDS" stands for, but fewer people know the precise difference between being HIV-positive and having AIDS. And the reason is that there are two official definitions, one by the Centers for Disease Control and Prevention (CDC) ${ }^{6}$ and one by the World Health Organization (WHO). ${ }^{7}$ The CDC definition takes into account a biological marker, the $\mathrm{CD} 4+$ cell count, and/or the presence of one or several opportunistic infections that are part of an official list (revised in 1993); the WHO definition (revised in 2007) only takes into account clinical manifestations, and can therefore be used in contexts where CD4+ cell count testing is not available. This twotier system reflects and aims to manage the heterogeneity of the epidemic, ${ }^{8}$ but it also causes the very name of the disease to be unstable. The focus of this paper being the diachronic dimension of the specialized language of AIDS, it is interesting to point out that, when the CDC definition was revised in 1993, the inclusion of the CD4+ cell count aimed to make the definition of AIDS more encompassing. In that respect, the following example is noteworthy; it so happens that, when the CDC revised the definition of AIDS, writer David Feinberg had already been tested positive for HIV, and the broadening of the definition of AIDS resulted in his fitting the new definition, as he mentions in Queer and Loathing:

I'm getting AIDS this Wednesday, April 19, at 12:01 AM because my T-cells have consistently been under 200 for the past year and the Center for Disease Control's definition of AIDS is scheduled to change on April 1 to include [...] the fewerthan-200 T-cells criteria. April fool! I've got AIDS. (1994: 90)

Given that AIDS is the final stage of HIV infection, ${ }^{9}$ crossing the threshold between "being HIV-positive" and "having AIDS" is quite significant, as author Mark Doty points out in Heaven's Coast:

For many people, there's a clear line of demarcation which marks the crossing from being HIV-positive to having AIDS. That's a telling grammatical distinction, the difference between being and having, between a condition and a possession. AIDS is a possession one is possessed by. (1996: 139) ${ }^{10}$

5 One last issue that needs to be raised is that of the name of the virus. Christening the virus was actually a several-step process: it was first dubbed "LAV" in 1983 (that was the name given by the French team who discovered it, and they chose cautiousness: "Lymphadenopathy-Associated Virus" was chosen because early AIDS patients usually 
suffered from a swelling of the lymph nodes); it was tagged "HTLV-III" in 1984 (that was the name given by the American co-discoverer, who thought the virus was bound to be a close relative of the retroviruses he had already discovered, "HTLV-I" and "HTLVII"-it turned out not to be the case), and it ended up being called "HIV," which is actually a compromise agreed upon in 1986 by the International Committee on the Taxonomy of Viruses in the midst of the feud between the two teams. Interestingly enough, in one of the most recent AIDS novels, A Horse Named Sorrow (2012), whose plot is set in the early years of the epidemic, Trebor Healey goes so far as to avoid naming the virus altogether:

Jimmy came from Buffalo, New York, and he had the acronym with him on the train platform the day I met him. [...] "I got something I gotta tell ya." He stared for another second. "I got it." Any faggot worth his salt knew what it was too. [...] The mother of all acronyms. [...] I don't dignify it with a name. (2012: 5-76)

6 The question that needs to be asked to conclude this first section is the following: is the language of AIDS a specialized language? No such book as a dictionary of HIV/AIDS exists, but the "Terminology Guidelines" regularly published and revised by UNAIDS come close. UNAIDS is the Joint United Nations Programme on HIV/AIDS, and it freely provides a number of reference documents that include the "Terminology Guidelines," the latest version (published in 2015) being a sixty-page booklet whose first two sentences are worth quoting: "Language shapes beliefs and may influence behaviours. Considered use of appropriate language has the power to strengthen the global response to the AIDS epidemic" (2015: 3). The first part of the booklet, entitled "Preferred terminology," consists in a table that features, on the left-hand side, the phrases and terms you are not to use and, on the right-hand side, those you should prefer: for example, page 8, it is recommended not to use "fight and other combatant language (e.g., struggle, battle, campaign or war)," the explanation (given in the middle column of the table, entitled "Background") being the following: "Avoid such terms unless in a direct quotation or because of the specific context of the text. One rationale for this is to avoid transference from the fight against HIV to a fight against people living with HIV." The proposed alternatives are: "response, management of, measures against, initiative, action, efforts and programme." ${ }^{11}$ The second part of the booklet seems to me to be very similar to a specialized dictionary; it is entitled "Useful background to selected terms," and it features such definitions as the following for the term "epidemic":

\footnotetext{
An epidemic refers to a disease condition affecting (or tending to affect) a disproportionately large number of individuals within a population, community or region at the same time. The population may be all of the inhabitants of a given geographic area, the population of a school or similar institution or everyone of a certain age or sex (such as the children or women of a region). An epidemic may be restricted to one locale (an outbreak), be more general (an epidemic) or be global (a pandemic). Common diseases that occur at a constant but relatively high rate in the population are said to be endemic.

Widely known examples of epidemics include the plague of medieval Europe (known as the Black Death), the influenza pandemic of 1918-1919 and the current HIV epidemic, which is increasingly described as a pandemic made up of distinct types of epidemics in areas across the globe. (2015: 19)
}

7 The very existence of a specialized, albeit partial, dictionary, seems to support the idea that the language of AIDS could be termed a specialized language. A closer look at the Tales of the City series, however, reveals that there is more to the language of AIDS than 
terminology. Because AIDS first massively hit gay men, its language emerged in a "discourse community" (Swales 1990) that already had its own code: what can be referred to as "Lavender language" actually consists in using non-specialized language in such a way as to ensure understanding between the members of the communityand exclusion of the non-members.

8 According to Bill Leap, the co-coordinator of the 2003 [Lavender Language and Linguistics] conference, homosexuals communicate with each other in ways that are "different from the linguistic practices of non-lesbian/gay-identified persons." Macmillan English dictionary explains that "Lavender language functions as a kind of homosexual code, characterized by acronyms, plays on words and double meanings only intended to be understood by the gay community" (Smorag 2008: 3).

\section{The "before" picture}

Whether the language of AIDS can be termed "specialized" or not, it has markedly evolved ever since the beginning of the epidemic. Because the nine volumes of the Tales of the City series span over three decades (1978-2014), they follow its evolution, especially when it comes to the "before" and "after" pictures, the great divide being the development in 1996 of antiretroviral therapies, also known as the AIDS cocktail. ${ }^{12}$ The development of the AIDS cocktail was a "game changer" 13 in the history of the epidemic: it resulted in a fast, dramatic decline in the number of AIDS-related deaths in the West in general and in the U.S. in particular. Therefore, 1996 is the year when HIV/ AIDS ceased to be a systematically fatal disease. ${ }^{14}$

The pre-"AIDS cocktail" era is thus a period of time during which "a diagnosis was a death sentence." ${ }^{15}$ In this statement, the word "diagnosis" seems to be self-sufficient; the nature of the diagnosis, the fact that it is either an "HIV diagnosis" or an "AIDS diagnosis," is not specified. It is actually a common use of the word "diagnosis," in its different forms, in the Tales of the City series; another example is the following: "Diagnosed several weeks before Rock Hudson's announcement, Geordie had lasted almost two years longer than the movie star [...]." This is on page six of the sixth volume in the series (Sure of You, 1989), and the word "AIDS," i.e., what Geordie was diagnosed with, does not appear until page fourteen, which means that the author counts on the fact that any reader "worth his salt" knows what the diagnosis was, notably thanks to the "Rock Hudson" clue. The readers who do not know that Rock Hudson died of AIDS are left in the dark, even though they know what the word "diagnosis" means, which illustrates the following point made by Paltridge and Starfield: "One difficulty with identifying vocabulary for ESP is what to do with everyday words that take on a particular meaning in a specialized context" (2013: 127). Another instance of an everyday word that has a particular meaning in the "before" picture is the word "safe": "safe sex" refers to the strategies that can be used to have sex and reduce the risk of HIV acquisition and transmission. ${ }^{16}$ In the fourth volume (Babycakes, 1984), the word "safe" appears on an ad for a jewelry company which offers pieces of jewelry that read "I'M SAFE" and advertises them as follows:

Dating is growing more and more complicated every day. Herpes, AIDS... If you are socially active it can be awkward and embarrassing to ask. How do you let someone you're interested in know that YOU ARE SAFE? Now you can let others know simply by wearing your "I'M SAFE" ring or pendant. The jewelry does the "talking" for you. (1984: 81) $)^{17}$ 
11 It is not said (on the jewels) what it is you are safe from because the context makes it unnecessary to be more specific.

In San Francisco in the early years of the HIV/AIDS epidemic, which is the setting of those novels, it went without saying that what people wanted to be safe from was, mostly, the virus that causes AIDS, and the fact that christening it was a several-step process (as mentioned earlier) shows in the fifth volume (Significant Others, 1987), when "HTLV-III" is used (87) - "HIV" appears later in the series. There are several instances in the sixth volume (Sure of You, 1989) where it is simply put: "the virus" $(153,175$ and 251). It is not to be seen as an effort made by the characters, i.e., laypersons, to avoid medical or scientific jargon; as a general rule, specialized terms are not avoided in the Tales of the City series, and in AIDS fiction in general: in the sixth volume, one character discovers on his body a lesion due to Kaposi sarcoma, an opportunistic infection typical of AIDS, and it is only phrased in its acronymic form, "K.S." (226). Readers who do not know what "K.S." is are not provided with a footnote or a glossary to help them. In a play by Tony Kushner entitled Angels in America, in which the character is in the exact same situation (having discovered a Kaposi sarcoma lesion on his body), he says:

K.S., baby. [...] I'm going to die. [...] No wall like the wall of hard scientific facts. K.S.

Wham. Bang your head on that. (1995: 27-28)

13 Scientific jargon is not the only wall you can "bang your head on" in AIDS fiction: probably the most compelling example of a saying that is bound to leave many readers puzzled is to be found in the fifth volume of the Tales of the City series (Significant Others, 1987), when one of the characters says that "some people won't even date outside their own antibody type" (301), meaning that some HIV-negative people are unwilling to choose HIV-positive people as their partners, and vice-versa. The use of humor complicates matters even further: the puns that can be made with the word "positive" actually require the speaker to be aware of the specialized meaning of "positive" in this context, since it is another instance where, more often than not, "positive" is used on its own, without "HIV" being specified. In the sixth volume (Sure of You, 1989), the main character's mom is not aware of this specialized meaning and therefore tells her son that he "should be positive about" his disease. Indirect free speech follows, in which the reader has access to Michael's thoughts: "How like her not to know that she'd made a pun." Then he answers "I am, Mama" (175)-the joke is between the author, the character and the informed reader, and on Michael's mom.

To conclude on this part, it is interesting to notice that silence takes on a new meaning too. As mentioned earlier, in the sixth volume (Sure of You, 1989), Michael discovers a Kaposi sarcoma lesion on his body, but the only time the acronym "K. S." is written down on the page is when the reader has access to Michael's thoughts: the word is actually not uttered by the characters, either by himself or by his partner, to whom, as he shows the purple mark on his ankle, he says, "Does that look like it?" (200), without specifying what "it" designates, because there are no two ways about it, as this scene in David Feinberg's novel Spontaneous Combustion illustrates:

[The waiter told us:]

"I'm starting on medical disability tomorrow."

We knew that it could be only one thing. Words were not necessary in this day and age. (1991: 8)

What may be concluded from this look at the "before" picture is that, in the early years of the epidemic, the language of AIDS is pregnant with implications, innuendoes, 
because words and silences are heavy with the prospect of death. It is now worth looking at what happens when this weight is lifted.

\section{The day after, and beyond}

16 In the seventh volume (Michael Tolliver Lives, 2007, i.e., the first volume that was published after 1996 and the development of the AIDS cocktail), ${ }^{18}$ what is salient in terms of specialized language is that the scientific jargon mentioned earlier is still a "wall" you might "bang your head on," but it now refers to what allows Michael to live; specialized medical terms are still used, but they now designate the drugs Michael takes on a daily basis:

My current recipe for continued existence, a fine-tuned mélange of Viramune and Combivir, now competes for shelf space in my medicine cabinet with Lipitor, Wellbutrin, and Glucosamine Chondroitin... (2007: 19)

Uninformed readers may be able to figure out that "Viramune" and "Combivir" are antiretroviral drugs and that "Lipitor" is a cholesterol-lowering drug, but "Wellbutrin" and "Glucosamine Chondroitin" are nowhere near self-explanatory: they are, respectively, an anti-depressant and a drug used to treat arthritis-conditions that are not linked with his being HIV-positive. As regards this point, in the "after" era, the use of the word "positive" on its own is less systematic and alternates with the phrase "HIV-positive"; one instance echoes the pun on the word "positive" that was quoted earlier: when Michael tells Ben (the younger man he will end up marrying), "You should know [...] I'm positive," Ben answers: “About what?." Here, the pun is obviously intentional, since Michael retorts: "Don't get smart with your elders" (2007: 12).

It has to be noted that there are still a few remains, a few elements of specialized language that seem to be grounded in the "before" era, but have actually outlived 1996 and the end of the AIDS crisis: the best example is probably that of the use of the term "T-cells" (Maupin 2007: 19), a term that was discarded by the scientific community when it was subsequently discovered that HIV did not target all T-cells, only CD4+ cells. There is no doubt that an HIV-positive person taking antiretroviral drugs is aware of it, because his/her CD4+ cell count is a number he/she keeps track of. ${ }^{19}$ This time, such an inaccuracy cannot be thought of as a choice of words made in order for everyone to understand what is being referred to: although "T cell" may sound a little less barbaric than "CD4+ cell," it still has a referent in the extralinguistic world that most people are unable to grasp (it would have been different if he had used "white blood cells," of which CD4+ cells are a type). So, this time, it does not seem to be about readability, clarity; it seems to me it can only be understood as a remnant of days gone by, a phrase that has stuck around for several decades.

19 This leads to the conclusion that, to a certain extent, the AIDS crisis has left a scar on language, much like it has left a scar on literature. The field of research the door to which this paper has been opening can be thought of as the linguistic twin to this literary evolution. To my knowledge, it is a field that has not been studied yet, contrary to its literary counterpart. 


\section{Conclusion}

Several defining features of "Fiction à substrat professionnel" (FASP) according to Michel Petit (1999) seem to fit the Tales of the City series, notably the fact that they are American international best sellers and quite consensually not considered "serious" literature (17). But several other features are not found however, in the Tales of the City series and many other literary works that also belong in the "AIDS literature" category. The one feature that is worth reflecting upon is that of the links that bind the author to the domain (which Petit refined in 2004): what is usually referred to as "AIDS literature" consists of works whose authors are not health professionals, ${ }^{20}$ and not even necessarily people living with HIV or AIDS. In his inaugural class at the College de France, former Executive Director of UNAIDS Peter Piot (2010) stated that the most powerful impact of the HIV/AIDS epidemic had been the emergence of groups (belonging to civil society) who became "experts of experience"; those groups filled the vacuum left by the establishment in the early years of the epidemic, and although they have met with some amount of resistance, notably on the part of the medical establishment, they have been the spearhead of the response to the HIV/AIDS epidemic, and their legitimacy, built over more than three decades (and especially during the first decade, when HIV/ AIDS spread among them in relative, virtually complete, indifference) is unquestionable. In the West in general, and in the U.S. in particular, the gay community has been one of those groups, and may arguably be thought of as the group that has had the most tremendous impact on the language of AIDS, notably with the books and the associations that have been mentioned in this paper. What may sound counterintuitive is that those groups are much broader than just people living with HIV/AIDS: they also encompass what gay people usually call their "families," a term used in the Tales of the City series to designate the network of characters whose links are neither biological, nor legal but "logical." ${ }^{21}$ A specialist in American civilization whose work notably focuses on collective identity, Guillaume Marche, calls "homosexual families" "various types of unconventional clusters of persons, that [homosexual people] explicitly consider their families" (2003: 100, my translation). As a consequence, in order to comprehend both the epidemiological and sociological realities of the HIV/AIDS epidemic, it is necessary to acknowledge that the "experts of experience," whose knowledge is solid and legitimate, are not only health professionals or "AIDS patients," 22 but all the people on whose lives HIV/AIDS has had such a significant impact that they have de facto become experts. The few authors mentioned in this paper actually constitute a relatively representative sample: Armistead Maupin is an HIV-negative gay man whose partner of many years, Terry, was HIV-positive; Larry Kramer is an HIV-positive gay man who has stated on several occasions that he has lost a hundred and twenty friends and acquaintances to AIDS; David Feinberg was a gay man and he died of AIDS in 1994, at age thirty-eight, after he lost many friends to AIDS; ${ }^{23}$ Mark Doty is an HIV-negative gay man whose partner Wally died of AIDS; playwright Tony Kushner is an HIV-negative gay man with no "first hand" experience of HIV/AIDS other than his being part of the gay community, a community whose destiny is inextricably linked with the AIDS crisis:

Even when a contemporary gay writer consciously eschews thematizing AIDSbecause he is unwilling or unable to do so-he no longer can write the innocent certainties that his pre-AIDS counterparts could take for granted. (Nelson 1992: 2) 
As a consequence, it might be more accurate to call the substrate "societal" instead of "professional." Could "Fiction à Substrat Sociétal," or FASS, be a useful device in the ESP tool belt? Rather than a specialized language stricto sensu, the language of AIDS may be thought of as an interface between specialized and non-specialized language. Therefore, viewing "AIDS literature" as FASS might, in the future, provide new insights into such questions as that of readership (the discrepancy between the implied reader and the actual reader, which is much discussed in literary analysis, may, in FASS, have to do with the degree of language specialization) and authorship (how loose, or tangential, can the ties that bind an author to a domain be?). The issue that lies at the bottom of such questioning is that of identity-the construction of identity through language and literature, the preservation of identity in illness and death through language and literature. According to Paltridge and Starfield: "Identity continues to be a research interest in the area of ESP" (2013:3).

\section{BIBLIOGRAPHY}

\section{Primary sources}

MAUPIN, Armistead. All volumes: New York: Harper.

Tales of the City (First volume), 1978.

More Tales of the City (Second volume), 1980.

Further Tales of the City (Third volume), 1982.

Babycakes (Fourth volume), 1984.

Significant Others (Fifth volume), 1987.

Sure of You (Sixth volume), 1989.

Michael Tolliver Lives (Seventh volume), 2007.

Mary Ann in Autumn (Eighth volume), 2010.

The Days of Anna Madrigal (Ninth volume), 2014.

\section{Secondary sources}

"1993 Revised Classification System for HIV Infection and Expanded Surveillance Case Definition for AIDS Among Adolescents and Adults." CDC Morbidity and Mortality Weekly Report December 18, 1992, accessed on October 22, 2016. <http://www.cdc.gov/mmwr/preview/mmwrhtml/ 00018871.htm>

BAXTER, Daniel J. 1997. The Least of These My Brethren. A Doctor's Story of Hope and Miracles on an Inner-City AIDS Ward. New York: Harmony.

CALLEN, Michael. 1990. Surviving AIDS. New York: Harper.

COUSER, G. Thomas. 2009. Signifying Bodies. Disability in Contemporary Life Writing. Ann Arbor: University of Michigan Press. 
DOTY, Mark. 1996. Heaven's Coast. London: Vintage.

FEINBERG, David B. 1991. Spontaneous Combustion. New York: Penguin.

FEINBERG, David B. 1994. Queer and Loathing. Rants and Raves of a Raging AIDS Clone. New York: Penguin.

FRANK, Arthur W. 1995. The Wounded Storyteller. Body, Illness and Ethics. Chicago: University of Chicago Press.

GALE, Patrick. 1999. Armistead Maupin. Bath: Absolute.

HEALEY, Trebor. 2012. A Horse Named Sorrow. Madison: University of Wisconsin Press.

HILLSBERY, Kief. 2001. “Love's Labor.” POZ Magazine, accessed on May 23, $2016<\mathrm{https}$ //

www.poz.com/article/Love-s-Labor-1068-4814/get-pdf>.

KRAMER, Larry. 1990. Reports From the Holocaust. The Making of an AIDS Activist. New York: Penguin.

KUSHNER, Tony. 1995. Angels in America. A Gay Fantasia on National Themes. New York: Theatre

Communications Group.

MARCHE, Guillaume. 2003. "Les familles homosexuelles aux États-Unis : dissolution d'un

mouvement social ou redéfinition de sa portée politique ?.” Revue Française d'Études Américaines 97, 99-117.

NELSON, Emmanuel S. (ed.). 1992. AIDS. The Literary Response. New York: Twayne.

PALTRIDGE, Brian \& Sue STARFIELD (eds.) 2013. The Handbook of English for Specific Purposes. Boston: Wiley-Blackwell.

PETIT, Michel. 1999. "La fiction à substrat professionnel : une autre voie d'accès à l'anglais de spécialité.” ASp 23/26, 57-81.

PETIT, Michel. 2004. "Quelques réflexions sur la fiction à substrat professionnel : du général au particulier." In PETIT, M. \& S. ISANI (eds.), Aspects de la fiction à substrat professionnel. Bordeaux: Université Victor Segalen Bordeaux 2, 3-23.

PIOT, Peter. 2010. "L'évolution d'une épidémie à plusieurs vitesses.” Collège de France (Chaire "Savoirs contre pauvreté"), accessed on May 23, 2016 <http://www.college-de-france.fr/site/ peter-piot/course-2009-2010.htm>.

SMORAG, Pascale. 2008. "From Closet Talk to PC Terminology: Gay Speech and the Politics of Visibility." Transatlantica 1, 1-17, accessed on May 23, 2016 <https://transatlantica.revues.org/ 3503>.

SONTAG, Susan. 1990. Illness as Metaphor and AIDS and its Metaphors. New York: Picador.

"UNAIDS Terminology Guidelines. Revised Version." 2015. UNAIDS, accessed on May 23, 2016 <http://www.unaids.org/sites/default/files/media_asset/2015_terminology_guidelines_en.pdf>. SWALES, John. 1990. Genre Analysis: English in Academic and Research Settings. Boston: Cambridge University Press.

"WHO Case Definitions of HIV for Surveillance and Revised Clinical Staging and Immunological Classification of HIV-Related Disease in Adults and Children." 2007. World Health Organization, accessed on October 22, 2016. <http://www.who.int/hiv/pub/guidelines/HIVstaging150307.pdf>. WILDE, Oscar. 2007 [1890]. The Picture of Dorian Gray. Ed. Andrew Elfenbein. NY: Pearson Longman. 


\section{NOTES}

1. As is mentioned in Armistead Maupin by Patrick Gale, Maupin claims that Babycakes, the fourth volume in the Tales of the City series, was "the first fiction published anywhere to acknowledge AIDS" (1999: 79); so far, I have not found any evidence to dispute his claim.

2. It is the commonly accepted term to refer to novels, plays and poems that focus on AIDSrelated issues, but it is not entirely satisfactory, since the word "literature," in a medical context, often designates articles published in specialized, scientific journals.

3. Those novels stand side by side with AIDS autobiographies, biographies and memoirs, works that are usually gathered under such terms as "pathographies," "autopathographies," "illness writing," etc. Those works, as opposed to works of fiction, have been at the center of scholarly attention in recent years when it comes to "disability studies," as Thomas Couser explains in his seminal work Signifying Bodies. Disability in Contemporary Life Writing: “[M]any scholars' attention turned to forms of life writing more accessible to women and other marginalized groups: letters, diaries, journals, testimonio and other forms of witnessing [...]. The term life writing came into use as an umbrella term to cover a wide range of not necessarily literary discursive practices devoted to representing the lives of real individuals" (2009: 12).

4. This term was famously used by activist and writer Larry Kramer in his seminal essay " 1,112 and counting," first published in the New York Native in 1983 and later included in his collection Reports from the Holocaust (1990: 36).

5. The goal is to refer to this "period of time [over which the way] people think of themselves and their world has changed enough to deserve a label, and the most accepted label [...] is postmodernism," and over this period of time "illness has come to feel different [...] and today the sum of those differences can be labeled postmodernism" (Frank 1995: 96).

6. The CDC is an American federal agency. See the "Works Cited" section for its 1993 definition.

7. WHO is an agency of the United Nations. See the "Works Cited" section for its 2007 definition.

8. On a world scale, it is actually more accurate to talk about the HIV/AIDS epidemic.

9. According to the $\mathrm{CDC}$ definition.

10. On that topic, the relatively recently created field of research that is pyschoneuroimmunology (PNI) aims to investigate the interactions between the psyche, the mental processes, and the nervous and immune systems, in other words, how it works when the mind has an impact on the body. One example is when David Feinberg writes: "Oddly enough, I feel that things began deteriorating for me in January" (1994: 94); as Feinberg was writing this, he actually only had a few months left to live: he died in 1994.

11. These recommendations echo Susan Sontag's 1978 book, Illness as Metaphor, in which she advocates the "demetaphorisation" of the language of illness, especially when it comes to "the language of warfare" (Sontag 1990: 64). Illness as Metaphor was published in 1990 together with AIDS and its Metaphors.

12. In French, they are usually called "trithérapies," which is another inaccuracy: they consist in a combination of several antiretroviral drugs, but not necessarily three.

13. This is a phrase used by Peter Piot in his inaugural class at the Collège de France (2010).

14. The "Terminology guidelines" actually recommend not using either the term "deadly" or the terms "chronic" and "manageable" about AIDS: the fact is that, nowadays, people can live with HIV/AIDS if they know they are HIV-positive, if they have access to antiretroviral therapies and if they take them consistently-those three "ifs" significantly qualify the statement that "AIDS is not a fatal disease anymore."

15. "I remember when a diagnosis was a death sentence" is a sentence attributed to Jim Graham, a pioneering figure in the field of AIDS politics in Washington, D. C. It is quoted by Michael Callen in his book Surviving AIDS (1990: 68). 
16. UNAIDS actually recommends using "safer sex," because "safe sex [...] may imply complete safety" (11), which is inaccurate. The phrase "safe-sex" is found in the fifth volume of the Tales of the City series (Significant Others, 1987); interestingly enough, I only found very few instances of the hyphenated version of the phrase-the only other such instance I found is in Spontaneous Combustion by David Feinberg, when the narrator mentions the "safer-sex regulations" (1991: 77). 17. The euphemistic substitution of "socially" for "sexually" in "socially active" is also noteworthy.

18. The eighteen-year hiatus between Sure of You (1989) and Michael Tolliver Lives (2007) obviously creates a gap in this diachronic analysis of the language of AIDS in fiction. Such a gap proves difficult to bridge, since the development of the AIDS cocktail in 1996 virtually put an end to the publication of "AIDS fiction". To paraphrase Maupin himself, Michael Tolliver Lives may well be the first fiction to acknowledge AIDS again in the early 21st century.

19. Armistead Maupin obviously knows it, since his partner of many years, Terry, was HIVpositive-the use of the past tense is in order because they split: Terry is still alive, thanks to the AIDS cocktail, and they actually split not long after Terry went on antiretroviral drugs and ceased to have a sword of Damocles hanging over his head. In an interview, Maupin uses the phrase "cocktail divorce," a phrase that he "heard several times around town" that refers to the "phenomenon [that] happens with a serodiscordant couple when the guy who expected to die has a shot at living" (Hillsbery 2001: 2).

20. Of course there exist a number of books that deal with AIDS-related contexts and are authored by health professionals (The Least of These My Brethren by Daniel J. Baxter is one of them), but they are nowhere near as numerous as those that are not, and they are usually not included in what is referred to as "AIDS literature."

21. "Logical Family" is the title Maupin chose to give to a monologue he performed on few occasions, in reference to the logical family of his Tales of the City series, and also to the logical family to which he has come to belong, that of the Castro (San Francisco's "gay village") and, more broadly, the gay community.

22. "AIDS patient" is another phrase that the "Terminology Guidelines" recommend discarding since "most of the time a person with AIDS is not in the role of patient" (UNAIDS 2015: 10); it is still very commonly used, though.

23. His archives include his personal desk calendars up until 1993; they testify to the exponential nature of the number of his friends and acquaintances who died of AIDS: in 1991, there was only one; there were three in 1992; in 1993, there were at least five.

\section{ABSTRACTS}

Using Armistead Maupin's Tales of the City series (a nine-volume saga which chronicles the lives of a network of characters living in San Francisco), this paper examines the diachronic evolution of the specialized language of AIDS. It first attempts to delineate the language of AIDS, and asks whether or not it can be termed "specialized." Then it takes a closer look at the "before" picture and at the "after" picture, the great divide being 1996, the year when antiretroviral therapies were developed, changing the very nature of HIV/AIDS. It shows that, in the pre-AIDS era, words and silences are heavy with the prospect of death, and that, when this weight is lifted, language is left with some scars. The conclusion of this paper questions the links that bind the authors of 
"AIDS literature" to the specialized domain, using former Executive Director of UNAIDS Peter Piot's notion of "experts of experience."

Grâce aux Chroniques de San Francisco (Tales of the City), une saga en neuf volumes d'Armistead Maupin qui raconte en détail la vie d'un petit groupe de personnages vivant à San Francisco, cet article explore l'évolution diachronique du vocabulaire du SIDA. En premier lieu, il donne quelques éclairages sur le vocabulaire du SIDA et pose la question de sa nature spécialisée. Puis il examine plus précisément l' "avant" et l' "après," la césure étant 1996, année où les thérapies antirétrovirales ont été mises au point et, partant, où le VIH/SIDA a changé de nature. Il montre que, dans l' "avant," les mots et les silences portent le poids de la mort et que, quand ce poids est levé, le langage reste pourtant marqué. La conclusion de cet article met en question les liens qui unissent les auteurs de "littérature du SIDA" et le domaine spécialisé, en utilisant l'idée développée par l'ancien directeur de l'ONUSIDA, Peter Piot, d' “experts de l'expérience."

\section{INDEX}

Keywords: diachronic ESP, FASP, gay identity, literature, specialized fiction, specialized language of AIDS

Mots-clés: anglais de spécialité diachronique, FASP, fiction à substrat professionnel, identité gay, langue spécialisée du SIDA, littérature

\section{AUTHOR}

\section{CHRISTELLE KLEIN-SCHOLZ}

Christelle Klein-Scholz defended her Ph.D. dissertation, " 'I remember when a diagnosis was a death sentence': AIDS and death in gay literature" in 2014. Her current fields of research include: the body, illness/disease, and death in literature, the construction of identity in/through literature, and the specialized language of health and medicine. She teaches English at Lycée Victor Hugo in Marseille. klein_chr@yahoo.fr 